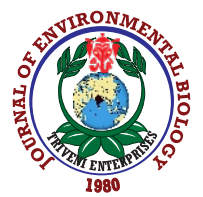

\title{
Comparative response of sorghum genotypes to varied levels of nitrogen in rice-fallows of North Coastal Region of Andhra Pradesh
}

\author{
B.S.S.S. Naik ${ }^{1 *}$, K.R. Murthy ${ }^{2}$ and T. Rupesh ${ }^{3}$ \\ 'Department of Agronomy, Acharya N.G. Ranga Agricultural University, Naira-532 185, India \\ ${ }^{2}$ Department of Agronomy, Acharya N.G. Ranga Agricultural University, RARS, Ragolu-532 484, India \\ ${ }^{3}$ Department of Soil Science and Agricultural Chemistry, Maharana Prathap University of Agriculture and Technology, Udaipur-313 001, India \\ *Corresponding Author Email : siddunaik08@gmail.com
}

Revised received: 03.10 .2020

Accepted: 30.10 .2020

\section{Abstract}

Aim: The objective of this research was to find a suitable variety and amount of nitrogen to work out their best combination for accomplishing higher productivity of Sorghum under rice fallow environment in Coastal Zone of South India.

\begin{abstract}
Methodology: An experimental trial was carried out with four sorghum genotypes viz., $\mathrm{V}_{1}-\mathrm{CSH} 15 \mathrm{R}, \mathrm{V}_{2}-$ $\mathrm{CSH} 16, \mathrm{~V}_{3}-\mathrm{CSH} 25$ and $\mathrm{V}_{4}-\mathrm{MLSH} 296$ and four nitrogen doses viz., $\mathrm{N}_{1}: 0 \mathrm{~kg} \mathrm{~N} \mathrm{ha}{ }^{-1}, \mathrm{~N}_{2}: 80 \mathrm{~kg} \mathrm{~N} \mathrm{ha}^{-1}, \mathrm{~N}_{3}$ : $100 \mathrm{~kg} \mathrm{Nha}^{-1}$ and $\mathrm{N}_{4}: 120 \mathrm{~kg} \mathrm{Nha}^{-1}$. The investigation was outlined in split plot design with three replications.
\end{abstract}

Results: Rice fallow sorghum genotype CSH 25 and supplementation of $120 \mathrm{~kg} \mathrm{~N}^{-1}$ had outstandingly recorded the highest grain weight, higher grain yield and physiological recovery of nitrogen among other genotypes. Nonetheless, in contrast to this, fodder yield was highest with hybrid CSH $15 R$ at $120 \mathrm{~kg} \mathrm{ha}^{-1}$, but apparent recovery of nitrogen (\%) and soil harvest nitrogen had recorded highest in $\mathrm{CSH} 16$ at same level of nitrogen (120 kg ha-1).

Interpretation: It can be terminated that sorghum growers under rice fallow conditions can opt for sorghum genotype $\mathrm{CSH} 25\left(\mathrm{~V}_{3}\right)$ with the supplementation of $120 \mathrm{~kg} \mathrm{~N} \mathrm{ha}^{-1}\left(\mathrm{~N}_{4}\right)$ for higher yield under rice fallow ecology of North Coastal Region of Andhra Pradesh in South India.

Key words: Genotypes, Grain yield, Rice-fallow, Sorghum

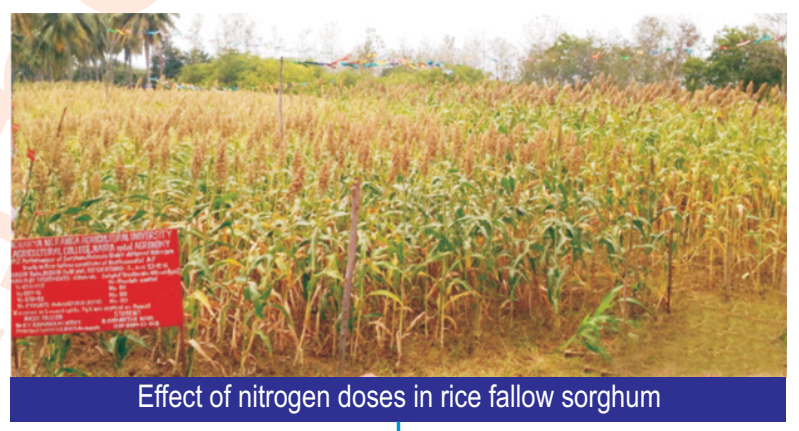

Main treatments: (Genotyes )

$\mathrm{V} 1$ - CSH -15R; V2 - CSH - 16

V3 - $\mathrm{CSH}-25$

V4 - Private Hybrid (MLSH-296)
$\mathrm{CSH} 25$ and supplementation of $120 \mathrm{~kg} \mathrm{~N} \mathrm{ha}^{-1}$ documented highest grain weight, higher grain yield and physiological recovery of $\mathrm{N}$ were obtained among other hybrids.

Fodder yield was highest with hybrid CSH 15 R at $120 \mathrm{~kg} \mathrm{ha}^{-1}$

> Apparent recovery of $\mathrm{N}(\%)$ and soil harvest nitrogen had registered highest with $\mathrm{CSH}$ 16 at the same highest level of $\mathrm{N}$ tried $\left(120 \mathrm{~kg} \mathrm{ha}^{-1}\right)$.

How to cite : Naik, B.S.S.S., K.R. Murthy and T. Rupesh: Comparative response of sorghum genotypes to varied levels of nitrogen in rice-fallows of North Coastal Region of Andhra Pradesh. J. Environ. Biol., 41, 1710-1718 (2020). 


\section{Introduction}

Sorghum (Sorghum bicolour L. Moench) is an utmost notable crop for millions of farmers in the semi-arid tropics in India. It re-emerges as a potential substitute food, feed, fodder and bio- energy crop. Although, part of sorghum crop area that has now been put back by maize, cotton and soybean is fetched to marginal area of soils. Rice-fallows offer an expansive scope to increase the country's winter crop area through decisive crop management operations (Mishra et al., 2018). Preference of relevant winter crop is pivotal and crop must have stress-adaptive features to combat the biotic and abiotic stresses particular to rice-fallow conditions (Kumar et al., 2018). Early to medium maturity, quick growth, superior ground cover and deep-roots have been recommended as desirable plant traits for waterlimited rice-fallow soils (Hazra and Bohra, 2020) .Cultivation of sorghum under rice-fallow soils assist as an alternative scenario to conventional agriculture for enhancing sustainable agricultural production due to growing issues like labour, fuel, water and nutrient deficiencies, particularly under winter environment. In rice-fallows of Coastal Andhra Pradesh, sorghum farming is obtaining acceptance among smallholders of farming due to its high productivity and low water requirement (Mishra et al., 2011). In rice-fallows with an average productivity of $6.5 \mathrm{t} \mathrm{ha}^{-1}$ in A.P., which is the highest in India, it is now grown in more than 26,000 ha. Farmers usually grow pulses (green gram and black gram) in rice-fallows in Andhra Pradesh's Krishna-Godavari delta zone as utera cropping (broadcasting seeds in standing rice crops).

Nevertheless, in current times, the area under pulse crops has drastically reduced due to late season sowing of legumes, poor germination due to low temperature, extreme attack of viral diseases and parasitic weed Cuscuta. Farmers of the region are now growing corn (in promised irrigated areas) and sorghum (in limited or bounded irrigated areas) in rice-fallows as replacement crops to pulses and legumes. It has given many economic and environmental advantage of conservation over traditional practices of tillage, such as lower labour and fuel consumption, reduced soil erosion, reduced runoff, increased soil organic carbon percentage and increased soil biological activity (West and Post, 2002).

Usually, growers of winter season in every area are using fertilizers and pesticides carelessly (Chapke et al., 2011). The input use by this great millet may vary with different cultivars or genotypes depending upon their growth ability and rooting pattern of expression. Nitrogen fertilization is fairly increasing its priority of essentiality in assessing the economic and environmental viability of agro-ecosystems and exploiting genotypic differences in nitrogen requirement, and efficiency has been suggested as potential and feasible options for diminishing costs and relying on nitrogen fertilizer (Gardner et al., 1994).

Balanced nutrition plays an essential role in the exploitation of yield potential of hybrids and high yielding varieties. The nutrients enhance crop vigour and photosynthetic assimilation area, which would help in the enlargement of large sink and superior yield (Naik et al., 2018a). Nitrogen is a crucial element in the determination of crop productivity in sorghum (Naik et al., 2018b). Intensive agriculture emphasizes drains on limited terrestrial supply of this critical element. It is not surprising to note that all over the globe today, the output of nitrogenous fertilizers is meagre to recoup the nitrogen lost from the soil by cropping and through other means. Only a small amount of nitrogen is retained in soil through precipitation, lightening etc. Henceforth, application of optimum dose of nitrogen plays an important role in realizing higher yields.

The findings of research trial have marked that the farmers are fascinated in grain sorghum only because they found only marginal variation between price of sorghum (Rs. 1500/- to 2000/- per $100 \mathrm{~kg}$ ) and corn (Rs. 1600/- to 2000/- per $100 \mathrm{~kg}$ ). Fourth important consideration was that a short duration crop like sorghum (100-120 days) is suitable to fit in crop rotation and fifth motive was, less insect-pest complications in sorghum in comparison to other crops. Thereupon, for last 6-12 years, farmers are cultivating sorghum after harvest of rice on the residual soil moisture under zero tillage. Several assuring sorghum hybrids have been developed by breeders and private companies for traditional sorghum growing areas, making it essential to scrutinize differential response of most promising or assuring hybrids to nitrogen in non-traditional zones such as ricefallows. The field study was, therefore, undertaken to determine the relative response of sorghum hybrids to varied levels of nitrogen in rice-fallows of North Coastal Region of Andhra Pradesh under South Indian Conditions.

\section{Materials and Methods}

A field experiment was piloted during rabi, 2016-17 at Agricultural Science of College, Naira. The soil was sandy loam in texture with a neutral $\mathrm{pH}$ of 7.42 and $\mathrm{EC}$ of $0.064 \mathrm{dSm}^{-1}$, medium in organic carbon $(0.56 \%)$, low in available nitrogen $\left(96 \mathrm{~kg} \mathrm{ha}^{-1}\right)$ and phosphorus (12.4 $\left.\mathrm{kg} \mathrm{ha}^{-1}\right)$, and medium in available potassium (151 $\left.\mathrm{kg} \mathrm{ha}^{-1}\right)$. The experiment was arranged in split plot design with three repetitions. The treatments constituted of four sorghum genotypes viz., $\mathrm{V}_{1}$ - CSH 15R, $\mathrm{V}_{2}-\mathrm{CSH} 16, \mathrm{~V}_{3}-\mathrm{CSH} 25$ and $\mathrm{V}_{4}$ MLSH 296 and four doses of nitrogen viz., $\mathrm{N}_{1}: 0 \mathrm{~kg} \mathrm{Nha}^{-1}, \mathrm{~N}_{2}: 80 \mathrm{~kg}$ $\mathrm{N} \mathrm{ha}^{-1}, \mathrm{~N}_{3}: 100 \mathrm{~kg} \mathrm{~N} \mathrm{ha}^{-1}$ and $\mathrm{N}_{4}: 120 \mathrm{~kg} \mathrm{~N} \mathrm{ha}^{-1}$. As the experiment was managed under zero till conditions, no ploughing and levelling operations were performed during cropping period. After the harvest of preceding paddy crop, the area was separated into prescribed number of plots as per field layout of the plan. Bold and healthy seeds (85-88 \% germination) were hand dibbled into the soil @ 2 per hill at a depth of $2-3 \mathrm{~cm}$ at a spacing of $45 \mathrm{~cm} \times 15 \mathrm{~cm}$ to secure optimum planting density. Nitrogen was applied in the form of urea $(46 \% \mathrm{~N})$ in 3 equal splits i.e., $1 / 3$ at 15 DAS and another $1 / 3$ at 45 days after first application and the remaining $1 / 3$ was top dressed at the time of flowering as per treatments. Entire 
dose of phosphorus was supplemented as single superphosphate $\left(16 \% \mathrm{P}_{2} \mathrm{O}_{5}\right)$ and $75 \mathrm{~kg} \mathrm{~K}_{2} \mathrm{O} \mathrm{ha}^{-1}$ was applied as murate of potash $\left(60 \% \mathrm{~K}_{2} \mathrm{O}\right)$ respectively, at the period of reproductive phenophase. The crop was grown on leftover soil moisture up to 10 DAS and consequently three irrigations were given, first at 30 DAS along with first top dressing of fertilizer application and second irrigation at $2^{\text {nd }}$ top dressing of fertilizer application (30 days after $1^{\text {st }}$ split application) and third irrigation at final top dressing of fertilizer application. Data on growth parameters like plant stand (initial and final count), SPAD, grain weight per panicle and number of leaves per plant were registered along with yield parameters like grain yield, straw yield. Nitrogen use efficiency indices like apparent recovery and physiological recovery were recorded. All the plants in $1.0 \mathrm{~m}^{2}$ area marked off in the net plot were enumerated at 15 days after sowing as initial, and final plant stand was recorded just before harvest. The number of leaves per plant of ten tagged plants per plot was counted at flowering stage. Chlorophyll content of matured leaves was determined SPAD meter. Five matured and lavish leaves of each hybrid plant per plot grown in zero tilled condition were measured after anthesis stage. Three measurements in the middle of leaf were made randomly for each plant and the average sample was used for analysis. The weight of hundred grains $(\mathrm{g})$ was noted from the grain samples drawn randomly from the net plot produce of each treatment. The weight were listed by using electronic digital balance and expressed in grams (g). Sun dried ears from net plot area were threshed, cleaned and weight of the grain was recorded as grain yield net plot per area. Grain yield per ha was worked out and expressed in $\mathrm{kg} \mathrm{ha}^{-1}$. The weight of stover from each net plot area was noted after leftover stalks in field for complete sun drying until a constant weight was obtained. The stover yield ha ${ }^{-1}$ was estimated and expressed in $\mathrm{kg} \mathrm{ha}^{-1}$. Nitrogen use efficiencies were calculated by using the formulas furnished below:

Physiological efficiency of nitrogen is the ability of fertilizer $\mathrm{N}$ consumed by the crop to increase yield. It was figured out by using the following formula given below:

Physiological efficiency of $\mathrm{N}=\frac{\begin{array}{c}\text { Grain yield in } \\ \text { treated plot }\end{array}-\begin{array}{c}\text { Grain yield in } \\ \text { control plot }\end{array}}{\begin{array}{l}\mathrm{N} \text { uptake in } \\ \text { treated plot }\end{array}}$

Apparent recovery of nitrogen is the fraction of nitrogen fertilizer withdrawn by the crop. It was calculated by using the subsequent formula given below:

$$
\begin{aligned}
& \mathrm{N} \text { uptake in } \mathrm{N} \text { uptake in } \\
& \text { Apparent recovery of } \mathrm{N}(\%)=\frac{\text { treated plot }^{-}{ }^{-} \text {control plot }}{\mathrm{kg} \text { of } \mathrm{N} \text { applied ha }{ }^{-1}} \times 100
\end{aligned}
$$

The initial soil samples collected before starting of experiment and final soil samples at post-harvest were drawn from each of the treatment plots and analyzed for available nitrogen (Subbiah and Asija, 1956), available phosphorous (Olsen et al., 1954) and available potassium (Jackson, 1973).

Statistical analyses: Gathered data were analyzed statistically by using R-program with agricolae package for split plot design. Least significant difference (LSD), as mean separation technique was tested to recognize the most efficient treatment by Panse and Sukhatame (1985) and Shrestha (2019).

\section{Results and Discussion}

The recorded data on growth parameters revealed that plant stand (initial and final count) of rice fallow sorghum genotypes showed non significant results with sorghum genotypes in conjunction with different nitrogen levels (Table 1). The number of leaves per plant of rice fallow sorghum genotypes did not differ with each other and interaction effect amidst the genotypes and nitrogen doses were not significant for number of green leaves per plant. At reproductive stage of 60 DAS, the number of leaves per plant altered with increase in nitrogen levels of dose range from 0 to $120 \mathrm{~kg} \mathrm{ha}^{-1}$ and recorded identical progression of data. It was achieved higher with $\mathrm{N}_{4}\left(120 \mathrm{~kg} \mathrm{ha}^{-1}\right)$ and was significantly higher than other levels of nitrogen except $\mathrm{N}_{3}\left(100 \mathrm{~kg} \mathrm{ha}^{-1}\right)$ with which it was commensurate. The number of leaves per plant obtained with $\mathrm{N}_{2}\left(80 \mathrm{~kg} \mathrm{ha}^{-1}\right)$ was in parity with all the levels of nitrogen doses, except $\mathrm{N}_{4}$. The lowest number of leaves per plant was recorded with $\mathrm{N}_{1}\left(0 \mathrm{~kg} \mathrm{ha}^{-1}\right)$ among the doses used in the experimental trial.

At 60 DAS of reproductive stage of rice- fallow sorghum, the number of leaves per plant showed a significant increase with each successive dose of nitrogen application rates. Increased nitrogen dose had increased plant height, produced more number of panicles and increased cell division and cell elongation rate. These attributes have bestowed higher number of leaves per plant. Similar results were found by Abbas et al. (2016) and Dixit et al. (2005) where number of leaves per plant had significantly increased by nitrogen levels from 40 to $180 \mathrm{~kg} \mathrm{~N} \mathrm{ha}^{-1}$.

Data pertaining to SPAD values of rice fallow sorghum hybrids did not differ with each other and their interaction effect between the hybrids and nitrogen levels was in significant.

At reproductive stage of $60 \mathrm{DAS}$, SPAD values varied with increase in nitrogen levels from 0 to $120 \mathrm{~kg} \mathrm{ha}^{-1}$.SPAD values obtained was higher with $\mathrm{N}_{4}\left(120 \mathrm{~kg} \mathrm{ha}^{-1}\right)$ and was significantly greater than other amounts of nitrogen, except $\mathrm{N}_{3}\left(100 \mathrm{~kg} \mathrm{ha}^{-1}\right)$ with which it was comparable. SPAD values enrolled with $\mathrm{N}_{2}(80$ $\mathrm{kg} \mathrm{ha}^{-1}$ ) was in parity with all the levels of nitrogen doses, except $\mathrm{N}_{4}$. The lowest number of leaves per plant was recorded with $\mathrm{N}_{1}(0$ $\mathrm{kg} \mathrm{ha}^{-1}$ ) among the doses tried in trial. Increased nitrogen quantity 
Table 1 : Effect of different genotypes and nitrogen levels on plant population, number of leaves per plant, and SPAD of rice fallow sorghum

\begin{tabular}{|c|c|c|c|c|}
\hline \multirow[t]{2}{*}{ Treatments } & \multicolumn{2}{|c|}{ Plant population } & \multirow{2}{*}{$\begin{array}{l}\text { Number of leaves } \\
\text { per plant }\end{array}$} & \multirow[t]{2}{*}{ SPAD } \\
\hline & Initial & Final & & \\
\hline \multicolumn{5}{|l|}{ Genotypes } \\
\hline CSH15R & 12.7 & 11.9 & 13.0 & 46.0 \\
\hline $\mathrm{CSH} 16$ & 12.9 & 12.5 & 12.5 & 46.0 \\
\hline $\mathrm{CSH} 25$ & 12.9 & 12.5 & 13.0 & 47.3 \\
\hline MLSH 296 & 12.9 & 12.7 & 12.1 & 46.0 \\
\hline SEm \pm & 0.20 & 0.23 & 0.22 & 0.57 \\
\hline$C D(P=0.05)$ & NS & NS & NS & NS \\
\hline \multicolumn{5}{|c|}{ N-levels (kg ha $\left.{ }^{-1}\right)$} \\
\hline 0 & 12.5 & 11.9 & 9.4 & 29.7 \\
\hline 80 & 12.9 & 12.5 & 11.6 & 48.5 \\
\hline 100 & 13.0 & 12.5 & 13.9 & 52.0 \\
\hline 120 & 13.0 & 12.7 & 15.0 & 54.5 \\
\hline SEm \pm & 0.21 & 0.27 & 0.22 & 0.63 \\
\hline $\mathrm{CD}(\mathrm{P}=0.05)$ & NS & NS & 0.79 & 1.8 \\
\hline \multicolumn{5}{|l|}{$\mathrm{H}$ at $\mathrm{N}$} \\
\hline SEm \pm & 0.24 & 0.09 & 0.44 & 1.10 \\
\hline$C D(P=0.05)$ & NS & NS & NS & NS \\
\hline \multicolumn{5}{|l|}{$\mathrm{N}$ at $\mathrm{H}$} \\
\hline SEm \pm & 0.22 & 0.08 & 0.44 & 1.23 \\
\hline $\mathrm{CD}(\mathrm{P}=0.05)$ & NS & NS & NS & NS \\
\hline
\end{tabular}

has extended chlorophyll green pigment load in leaves, produced more plant stature and accelerated cell division and cell elongation rate. Similar results were found with the experiment conducted by Buah and Mwinkaara (2009) and Ravindranath et al. (2019) where SPAD values were disported non-significant up to $120 \mathrm{~kg} \mathrm{Nha}^{-1}$.

Data relevant to grain weight per panicle of different hybrids of rice fallow sorghum as influenced by different doses of nitrogen are shown in Table 2. Grain weight per panicle data of rice fallow sorghum did not vary with nitrogen levels, meantime their interaction was found to be significant. Analysis of data concern to grain weight per panicle depicted that hybrids of rice fallow sorghum did not change with each other.

With respect to nitrogen levels tested in rice fallow sorghum, grain weight per panicle varied significantly with increase in nitrogen levels from 0 to $120 \mathrm{~kg} \mathrm{ha}^{-1}$. The results of data manifested that grain weight per panicle at the highest nitrogen level of $120 \mathrm{~kg} \mathrm{~N} \mathrm{ha}^{-1}\left(\mathrm{~N}_{4}\right)$ is significantly superior test weight as compared to all other levels of nitrogen tried. Grain weight per panicle obtained with the supplementation of $100 \mathrm{~kg}$ $\mathrm{ha}^{-1}\left(\mathrm{~N}_{3}\right)$ was the next best treatment but was, nonetheless, significant with the application of $80 \mathrm{~kg} \mathrm{ha}^{-1}\left(\mathrm{~N}_{2}\right)$. Both these nitrogen doses were significantly lesser to $\mathrm{N}_{4}$ and significantly higher to, no application of nitrogen $\left(\mathrm{N}_{1}\right)$, which achieved significantly least grain weight per panicle among all the four levels of nitrogen approved in this experimental trial.

Interaction effect between the hybrids and nitrogen levels for grain weight per panicle was found to be statistically significant. Grain weight was highest with the hybrid CSH 25 at $120 \mathrm{~kg} \mathrm{~N} \mathrm{ha}^{-1}\left(\mathrm{~V}_{3} \mathrm{~N}_{4}\right)$ which was on par with CSH 16 at $120 \mathrm{~kg} \mathrm{Nha}^{-1}$ $\left(\mathrm{V}_{2} \mathrm{~N}_{4}\right)$ and superior over other interaction combinations of synergy. The lowest grain weight per panicle was reported by $\mathrm{CSH} 15 \mathrm{R}$ at $0 \mathrm{~kg} \mathrm{~N} \mathrm{ha}^{-1}\left(\mathrm{~V}_{3} \mathrm{~N}_{4}\right)$, although it was on par with $\mathrm{CSH} 25$ at $0 \mathrm{~kg} \mathrm{Nha}^{-1}\left(\mathrm{~V}_{3} \mathrm{~N}_{1}\right)$ which was significantly inferior to all other combinations.

The increase in grain weight per panicle at higher dose of nitrogen might be due to greater assimilating surface at reproductive development resulted in better grain emergence because of adequate production of metabolites and their migration towards grain coming into being which showed improvement in nutrient concentration and uptake (Nagarajan et al., 2018). This might have outcome in increased number of individual grain per panicle and test weight expressed in terms of grain weight per panicle (Goutami et al., 2015). These results were in consonance with the findings of Patil (2013), Mishra et al. (2015) and Bartaula et al. (2019).

The data appertain to grain and forage yield of rice fallow sorghum is elucidated in Fig. 1. Findings of data on grain yield of 
Table 2 : Effect of different genotypes and nitrogen levels on grain weight per panicle, nitrogen use efficiencies i.e., apparent recovery and physiological efficiency of rice fallow sorghum

\begin{tabular}{|c|c|c|c|}
\hline Treatments & Grain weight per panicle & Apparent recovery of $\mathrm{N}(\%)$ & Physiological efficiency of $\mathrm{N}(\%)$ \\
\hline \multicolumn{4}{|l|}{ Genotypes } \\
\hline CSH 15R & 78.0 & 68.3 & 32.2 \\
\hline $\mathrm{CSH} 16$ & 108.5 & 80.1 & 23.0 \\
\hline $\mathrm{CSH} 25$ & 112.0 & 57.1 & 49.4 \\
\hline MLSH 296 & 96.5 & 48.2 & 43.1 \\
\hline SEm \pm & 2.86 & 5.6 & 4.9 \\
\hline$C D(P=0.05)$ & NS & 19.9 & 17.4 \\
\hline \multicolumn{4}{|c|}{ N-levels (kg ha ${ }^{-1}$ ) } \\
\hline 0 & 49.5 & 0 & 0 \\
\hline 80 & 90.1 & 50.3 & 77.4 \\
\hline 100 & 119.0 & 96.3 & 35.8 \\
\hline 120 & 136.3 & 101.2 & 34.9 \\
\hline SEm \pm & 2.93 & 3.5 & 3.9 \\
\hline$C D(P=0.05)$ & 10 & 10.4 & 11.5 \\
\hline \multicolumn{4}{|l|}{$\mathrm{H}$ at $\mathrm{N}$} \\
\hline SEm \pm & 3.09 & 11.3 & 9.6 \\
\hline $\mathrm{CD}(\mathrm{P}=0.05)$ & 32.5 & 22.8 & NS \\
\hline \multicolumn{4}{|l|}{$\mathrm{Nath}$} \\
\hline SEm \pm & 3.14 & 10.7 & 9.1 \\
\hline$C D(P=0.05)$ & 22.6 & 26.8 & NS \\
\hline
\end{tabular}

sorghum mentioned that yield obtained with $\mathrm{CSH} 25\left(\mathrm{~V}_{3}\right)$ was notably highly superior than all other genotypes, except CSH 16 $\left(V_{2}\right)$ with which it was statistically comparable or able to be likened to another (Fig.1). Grain productivity registered with MLSH 296 $\left(\mathrm{V}_{4}\right)$ was on par with all the genotypes, except CSH $25\left(\mathrm{~V}_{3}\right)$. The lowest grain productivity was reported with $\mathrm{CSH} 15 \mathrm{R}\left(\mathrm{V}_{1}\right)$ among all the hybrids taken for purpose of research study. Grain yield attained at highest nitrogen dose $\left(\mathrm{N}_{4}\right)$ was significantly superior or remarkable as compared to all the nitrogen doses tried. Yield obtained with $100 \mathrm{~kg} \mathrm{ha}^{-1}\left(\mathrm{~N}_{3}\right)$ supplementation was next best treatment, however, was comparable with $80 \mathrm{~kg} \mathrm{ha}^{-1}\left(\mathrm{~N}_{2}\right)$ supplementation. Both these nitrogen doses were significantly superior to $\mathrm{N}_{4}$ and significantly superior to no application of nitrogen $\left(\mathrm{N}_{1}\right)$, which gave significantly lowest grain productivity among all the four doses of nitrogen tested in this trial.

The outstanding ability of hybrid $\mathrm{CSH} 25\left(\mathrm{~V}_{3}\right)$ in terms of productivity under rice fallow circumstances of sorghum can be markedly attributed to its higher number of grains per panicle, dry matter accumulation at harvest as compared to rest of the three genotypes. It has also the potentiality to put up the growth under low temperature conditions at early stages. Similar observations were reported by Mishra et al. (2011) and Chapke et al. (2014) where $\mathrm{CSH}-25$ recorded highest yield with increasing level of nitrogen upto $225 \mathrm{~kg} \mathrm{~N} \mathrm{ha}^{-1}$ under rice fallow ecology of zero tilled conditions. Ramyasri et al. (2019) and Sanjana et al. (2020) were reported that increase in the grain production with enhanced $\mathrm{N}$ supplementation could be imputed to better plant growth and dry matter assimilation due to higher photosynthetic expansion area. This further supported by the fact that soil of the experimental field was low in nitrogen $\left(96 \mathrm{~kg} \mathrm{ha}^{-1}\right)$. These results are in authentication of affirmative with Madhukumar et al. (2013), Mishra et al. (2014), Prasad et al. (2014), Kumar et al. (2019), ElShater et al. (2020).

Fodder yield obtained with $\mathrm{CSH} 15 \mathrm{R}\left(\mathrm{V}_{1}\right)$ was significantly superior to all the genotypes. Forage yield with $\mathrm{CSH} 25\left(\mathrm{~V}_{3}\right)$ was found to be superior to all other genotypes, except $V_{1}$, whereas while productivity with $\mathrm{CSH} 16\left(\mathrm{~V}_{2}\right)$ was significantly superior to MLSH $296\left(V_{4}\right)$. Straw yield at highest nitrogen level $\left(N_{4}\right)$ was significantly superior as compared to all other levels of nitrogen doses tried. Stover productivity obtained with $100 \mathrm{~kg} \mathrm{ha}^{-1}\left(\mathrm{~N}_{3}\right)$ supplementation was the next or later best treatment but was, nonetheless, significant superior to $80 \mathrm{~kg} \mathrm{ha}^{-1}\left(\mathrm{~N}_{2}\right)$. No application of nitrogen $\left(\mathrm{N}_{1}\right)$ recorded significantly lowest yield among all the four levels of nitrogen tested in this experimental trial. Forage yield was highest with the genotype $\mathrm{CSH} 15 \mathrm{R}$ at $120 \mathrm{~kg} \mathrm{ha}^{-1}\left(\mathrm{~V}_{1} \mathrm{~N}_{4}\right)$ which was superior over other interaction combinations. The lowest stover productivity was produced by MLSH 296 at $0 \mathrm{~kg} \mathrm{~N}$ ha $^{-1}\left(\mathrm{~V}_{4} \mathrm{~N}_{1}\right)$ due to dwarf stature and lowest dry matter partioning. Higher stover yield with $\mathrm{CSH} 15 \mathrm{R}\left(\mathrm{V}_{1}\right)$ might be by reason of its tall growing nature as reflected by its highest plant height and also dry matter production. Similar observations were noted by Mishra et al. (2013) and Chapke et al. (2014). The highest stover yield 
Table 3 : Effect of different genotypes and nitrogen levels on final soil $\mathrm{N}, \mathrm{P}$ and $\mathrm{K}\left(\mathrm{kg} \mathrm{ha}^{-1}\right)$ of rice fallow sorghum

\begin{tabular}{|c|c|c|c|}
\hline Treatments & Final N & Final P & Final K \\
\hline \multicolumn{4}{|l|}{ Genotypes } \\
\hline CSH 15R & 148.6 & 8.5 & 207.7 \\
\hline CSH 16 & 155.7 & 8.1 & 184.0 \\
\hline $\mathrm{CSH} 25$ & 154.9 & 8.0 & 193.9 \\
\hline MLSH 296 & 123.8 & 8.5 & 194.8 \\
\hline $\mathrm{SEm} \pm$ & 1.93 & 0.28 & 9.87 \\
\hline$C D(P=0.05)$ & 6.8 & NS & NS \\
\hline \multicolumn{4}{|c|}{ N-levels (kg ha ${ }^{-1}$ ) } \\
\hline 0 & 88.5 & 5.9 & 137.7 \\
\hline 80 & 147.6 & 7.4 & 256.9 \\
\hline 100 & 159.9 & 9.1 & 198.4 \\
\hline 120 & 187.0 & 10.8 & 187.4 \\
\hline SEm \pm & 2.85 & 0.39 & 7.65 \\
\hline$C D(P=0.05)$ & 8.3 & 1.15 & 22.48 \\
\hline \multicolumn{4}{|l|}{$\mathrm{H}$ at N } \\
\hline SEm \pm & 5.3 & 0.5 & 16.5 \\
\hline$C D(P=0.05)$ & 16 & NS & 52 \\
\hline \multicolumn{4}{|l|}{$\mathrm{Nath}$} \\
\hline SEm \pm & 3.8 & 0.8 & 19.7 \\
\hline$C D(P=0.05)$ & 17.2 & NS & 48.2 \\
\hline
\end{tabular}

evidenced with $120 \mathrm{~kg} \mathrm{~N}$ ha $^{-1}$ application might be due to the fact that nitrogen supplementation increases cytokinin activity in plant which leads to augmented cell division and elongation and also perhaps because of its genetic constitution of yield attributing morpho-physiological parameters and maximum dry matter content (Wani et al., 2004; Madhukumar et al., 2013 and Ramyasri et al., 2018).

Apparent recovery (AR) (Table 2) obtained with CSH 16 $\left(V_{2}\right)$ was higher than all the other genotypes, except CSH 15R $\left(V_{1}\right)$ which was statistically comparable. AR recorded with $\mathrm{CSH} 25\left(\mathrm{~V}_{3}\right)$ was on par with all the genotypes, except CSH $16\left(V_{2}\right)$. The lowest AR was recorded with MLSH $296\left(V_{4}\right)$ among all the genotypes evaluated for the study. Apparent recovery at the highest nitrogen level $\left(\mathrm{N}_{4}\right)$ was superior as compared to all the other doses of imposed nitrogen treatments but was in parity with $100 \mathrm{~kg} \mathrm{ha}^{-1}$ $\left(\mathrm{N}_{3}\right)$. AR obtained with $100 \mathrm{~kg} \mathrm{ha}^{-1}\left(\mathrm{~N}_{3}\right)$ application was significantly superior to $80 \mathrm{~kg} \mathrm{ha}^{-1}\left(\mathrm{~N}_{2}\right)$. Significantly lowest AR among all the four doses of nitrogen tested in this demonstrative study was found with nil application of nitrogen $\left(\mathrm{N}_{1}\right)$.Apparent recovery was highest with the genotype CSH 16 at $120 \mathrm{~kg} \mathrm{ha}^{-1}\left(\mathrm{~V}_{2} \mathrm{~N}_{4}\right)$, which was superior over other interaction combinations except $\mathrm{V}_{2} \mathrm{~N}_{3}$, and the lowest AR was produced by MLSH 296 at $80 \mathrm{~kg} \mathrm{~N}^{-1}\left(\mathrm{~V}_{4} \mathrm{~N}_{2}\right)$. These results are in conformity with those reported by Singh et al. (2014), Yaa et al. (2017) and Huang et al. (2018).

Data related to physiological efficiency of nitrogen (PE) with sorghum indicated that efficiency obtained with $\mathrm{CSH} 25\left(\mathrm{~V}_{3}\right)$ was higher than all the other genotypes, except MLSH $296\left(\mathrm{~V}_{4}\right)$ with which it was statistically comparable. PE recorded with $\mathrm{CSH}$ $15 R\left(V_{1}\right)$ was on par with all the hybrids, except CSH $25\left(V_{3}\right)$. The lowest PE was recorded with $\mathrm{CSH} 16\left(\mathrm{~V}_{2}\right)$ among all the genotypes accepted for this study.

Physiological efficiency obtained at nitrogen level of $80 \mathrm{~kg}$ $\mathrm{ha}^{-1}\left(\mathrm{~N}_{2}\right)$ was recorded significantly superior as compared to all the nitrogen levels tried. PE obtained with $100 \mathrm{~kg} \mathrm{ha}^{-1}\left(\mathrm{~N}_{3}\right)$ application was next best treatment and significantly superior to nil application of nitrogen or control treatment $\left(\mathrm{N}_{1}\right)$, which recorded significantly lowest PE.

Out of the two efficiency indices of nitrogen resolved out for rice fallow sorghum, $\mathrm{CSH} 25\left(\mathrm{~V}_{3}\right)$ was found to be superior with respect to the physiological efficiency which clearly depicted the efficiency of that particular genotype to outperform the other three hybrids taken for research scrutiny. This was also reflected or reverted in the performance of this genotype with respect to growth, yield parameters and yield as well. With respect to ' $N$ levels and interaction, it can be presumed that no peculiar and appropriate progression of trend can be evidenced and, hence, valid and convincing conclusions cannot be drawn.

The perusal of data (Table.3) on post harvest soil nitrogen of sorghum indicated that soil nitrogen content reported with $\mathrm{CSH}$ $16\left(V_{2}\right)$ was significantly greater than all the other genotype, except CSH $25\left(\mathrm{~V}_{3}\right)$, while $\mathrm{CSH} 15 \mathrm{R}\left(\mathrm{V}_{1}\right)$ was on par with $\mathrm{CSH} 25$ $\left(V_{3}\right)$. Significantly lowest soil nitrogen recorded with MLSH 296 $\left(V_{4}\right)$. Soil nitrogen at highest nitrogen level $\left(\mathrm{N}_{4}\right)$ was significantly 


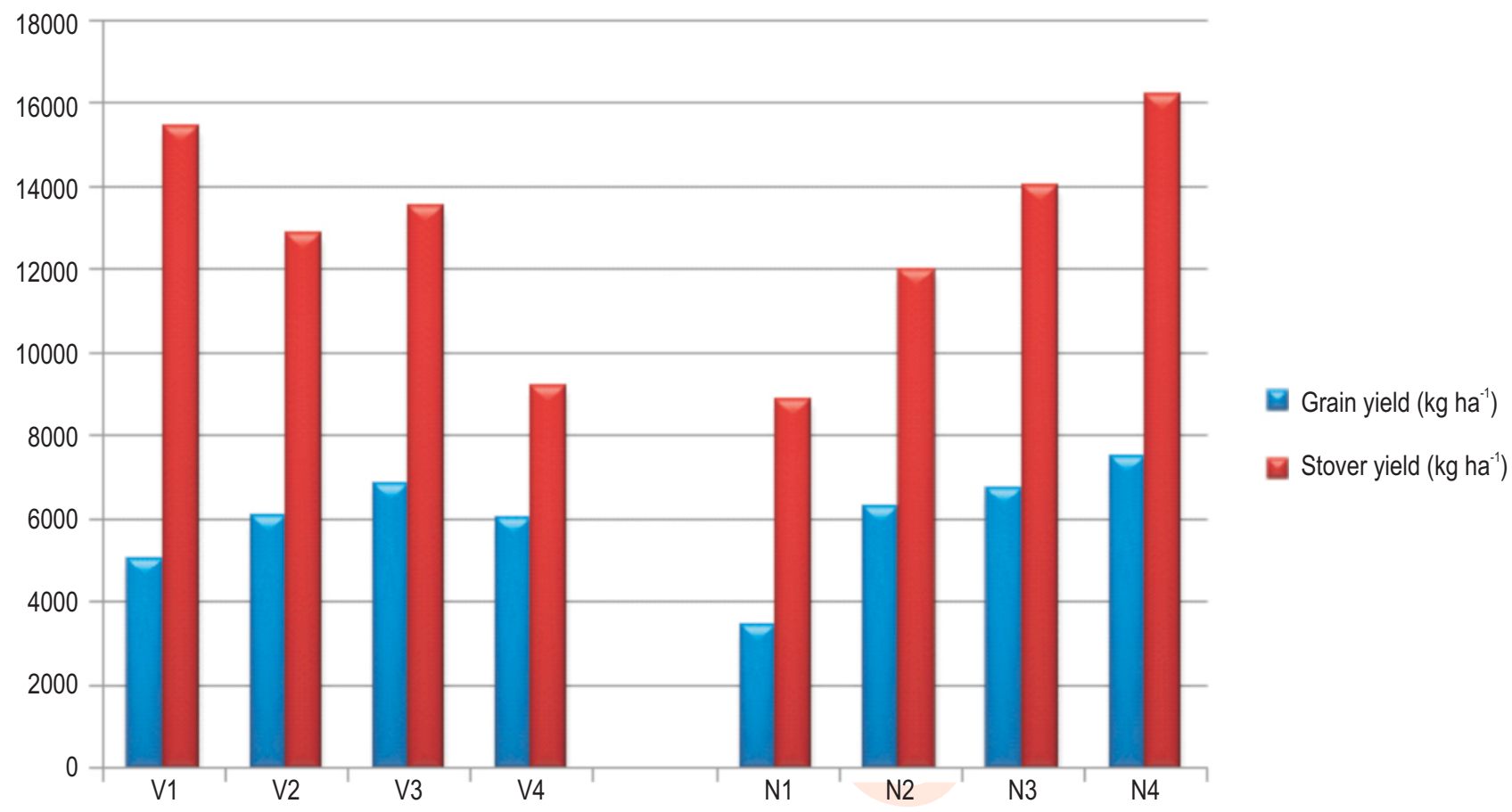

Fig. 1 : Effect of different hybrids and nitrogen levels on grain yield $\left(\mathrm{kg} \mathrm{ha}^{-1}\right)$ and stover yield $\left(\mathrm{kg} \mathrm{ha}^{-1}\right)$ of rice fallow sorghum. Main treatments: $\mathrm{V}_{1}$ - CSH 15R, $\mathrm{V}_{2}-\mathrm{CSH}-16, \mathrm{~V}_{3}-\mathrm{CSH}-25, \mathrm{~V}_{4}$ - Private Hybrid (MLSH-296), Sub treatments: $\mathrm{N}_{1}-$ Absolute control, $\mathrm{N}_{2}-80, \mathrm{~N}_{3}-100, \mathrm{~N}_{4}-120$.

superior as compared to all other levels of nitrogen tried. Soil nitrogen obtained with $100 \mathrm{~kg} \mathrm{ha}^{-1}\left(\mathrm{~N}_{3}\right)$ supplementation was the next prime treatment, however, was significant superior to $80 \mathrm{~kg}$ $\mathrm{ha}^{-1}\left(\mathrm{~N}_{2}\right)$.Both these nitrogen levels were significantly inferior to $\mathrm{N}_{4}$ but were significantly superior to nil application of nitrogen $\left(\mathrm{N}_{1}\right)$, which recorded significantly lowest final nitrogen among all the four levels of nitrogen assessed in this trial. Soil nitrogen was higher with genotype CSH $15 \mathrm{R}$ at $120 \mathrm{~kg} \mathrm{ha}^{-1}\left(\mathrm{~V}_{1} \mathrm{~N}_{4}\right)$ which was superior over other interaction combinations and the lowest soil nitrogen was reported with MLSH 296 at $0 \mathrm{~kg} \mathrm{~N}^{-1}\left(\mathrm{~V}_{4} \mathrm{~N}_{1}\right)$. Increase in post harvest soil nitrogen status due to increased doses of nitrogen supplementation owing to increment in root exudates acts as substrate for microorganisms and mineralize organic nitrogen, besides the possibility of accumulation of unused leftover nitrogen in the soil (Jyothi et al., 2016; Nigade and More, 2013).

Post harvest soil phosphorus did not vary with sorghum hybrids and were in significant. Soil phosphorus for $\mathrm{N}$ levels followed similar run as that of soil nitrogen, as interaction was in significant. Available phosphorus increased with increase in nitrogen level probably due to positive interaction of phosphorus with increased nitrogen application i.e., the acidifying effect of added nitrogen fertilizer enhances phosphorus solubility thereby increasing the availability of phosphorus and the role of improved soil structure of surface soil under zero tillage in offsetting negative effects of stratification on available - P distribution to the plants and leaving available phosphorus in the soil after harvest at higher nitrogen levels and vice versa (Reddy, 2019).

Post harvest soil potassium of rice-fallow sorghum genotypes did not differ with each other and were non-significant. Soil potassium with $80 \mathrm{~kg} \mathrm{~N}$ ha- $^{-1}\left(\mathrm{~N}_{2}\right)$ was significantly superior followed by application of $100 \mathrm{~kg} \mathrm{ha}^{-1}\left(\mathrm{~N}_{3}\right)$, which was in uniformity with $120 \mathrm{~kg} \mathrm{ha}^{-1}\left(\mathrm{~N}_{4}\right)$. All these nitrogen levels were significantly superior to no application of nitrogen $\left(\mathrm{N}_{1}\right)$, which recorded the significantly lowest soil potassium. Soil potassium was higher with hybrid MLSH 296 at $80 \mathrm{kgha}^{-1}\left(\mathrm{~V}_{4} \mathrm{~N}_{2}\right)$ and lowest soil potassium was detected with MLSH 296 at $120 \mathrm{~kg} \mathrm{Nha}^{-1}\left(\mathrm{~V}_{4} \mathrm{~N}_{4}\right)$. Potassium also followed similar pattern as that of phosphorus, i.e., potassium had synergistic effect with nitrogen thereby increased the availability of potassium at crop phenophases, leaving more available potassium after harvest at higher levels of nitrogen.

$\mathrm{CSH} 25\left(\mathrm{~V}_{3}\right)$ performed best in terms of growth, yield and nitrogen efficiency attributes due to high and proper utilization of residual moisture, nutrients and decomposed organic carbon in soil pools at good rate of mineralization intervals of left over straw residue of rice along with recommended doses of nitrogen by specific sorghum hybrids as taken up under zero tilled conditions of rice-fallows for this given problematic area of situation and, hence, was found most promising and relevant technology under concept of conservation agriculture to reduce the cost of cultivation for primary tillage labour operations, chemical inputs, 
energy and fuel consumption for North Coastal Zone of Andhra Pradesh in South India.

\section{References}

Abbas, A. and S.H. Hoseini: Effect of sowing dates and nitrogen levels for ethanol production from sweet sorghum stalks and grains. African J.Agric. Res., 11, 266-275 (2016).

Bartaula, S., U. Panthi, A. Adhikari, M. Mahato, D. Joshi and K. Aryal: Effect of different tillage practices and nitrogen level on wheat production under inner terai of Nepal. J. Agric. Nat. Res., 3, 233239 (2019).

Buah, S.S.J. and M. Mwinkaara: Response of sorghum to nitrogen fertilizer and plant density in the Guinea Savanna zone. J. Agron., 8, 124-130 (2009).

Chapke, R.R., J.S. Mishra, S. Babu, C. Aruna and J.V. Patil: On farm evaluation of advanced sorghum hybrids in rice fallows under zero tillage. Curr. Adv. Agric. Sci., 6, 180-182 (2014).

Chapke, R.R., J.S. Mishra, B. Subbarayudu, K. Hariprasanna and J.V. Patil: Sorghum cultivation in rice-fallows: A paradigm shift. Bulletin, Directorate of Sorghum Research, Hyderabad 500 030, India, ISBN: 81-89335-34-0:31p (2011).

Dixit, A.K., O.P. Singh, D. Kachroo and A.S. Bali: Response of promising rainy - season sorghum (Sorghum bicolor) genotypes to nitrogen and phosphorus fertilization. Indian J. Agron., 50, 206-209 (2005).

El-Shater, T., A. Mugera and Y.A. Yigezu: Implications of adoption of zero tillage on productive efficiency and production risk of wheat production. Sustainability, 12, 3640 (2020).

Gardner, J.C., J.W. Maranville and E.T. Paparozzi: Nitrogen-use efficiency among diverse sorghum cultivars. Crop Sci., 34, 28-33 (1994).

Goutami, N., P. Prasuna Rani, P. Ravindra Babu and R. Lakshmi Pathy: Performance of rice fallow sorghum as influenced by nutrient management. AndhraAgric. J. , 62, 334-338 (2015).

Jackson, M.L.: Soil Chemical Analysis. Prentice Hall of India Pvt. Ltd., New Delhi, pp.134-204. (1973).

Jyothi, K.N., V. Sumathi and N. Sunitha: Productivity, nutrient balance and profitability of foxtail millet varieties as influenced by levels of nitrogen. IOSR J. Agric. Vet. Sci., 9, 18-22 (2016).

Hazra, K.K. and A. Bohra: Increasing relevance of pulse crops to sustainable intensification of Indian Agriculture. Natl. Acad. Sci. Lett. (2020). https://doi.org/10.1007/s40009-020-00948-6

Huang, M., Z. Xuefeng and Z. Yingbin :Improving nitrogen management for zero-tillage rice in China. Crop J., 6. 406-412 (2018).

Kumar, R., J.S. Mishra, K.K. Rao, B.P. Bhatt, K.K. Hazra, H. Hans and S. Mondal: Evaluation of crop establishment techniques in ricefallows of Eastern Indo-Gangetic Plains. In: National Conference on Organic Waste Management for Food and Environmental Security under theme Theme Crop Residue Management. ICAR Indian Institute of Soil Science Bhopal, Madhya Pradesh, India (2018).

Kumar, D., R.A. Patel and V.P. Ramani:Assessment of precision nitrogen management strategies in terms of growth, yield and monetary efficiency of maize grown in Western India. J. PI. Nutr., 42., 28442860 (2019).

Madhukumar, M., P. Munirathnam and M. Srinivasa Reddy: Studies on the effect of nitrogen fertilization on growth and yield of sorghum (Sorghum bicolor) varieties during post rainy (maghi) season. AndhraAgric. J., 60, 760-763 (2013).
Mishra, J.S., B. Subbarayudu, R.R. Chapke and N. Seetharama: Evaluation of sorghum (Sorghum bicolor) cultivars in rice (Oryza sativa)-fallows under zero tillage. Indian J. Agric. Sci., 81, 277-279 (2011).

Mishra, J.S., R.R. Chapke, B. Subbarayudu, K. Hariprasanna and J.V. Patil: Response of Sorghum hybrids to nitrogen under zero tillage in rice fallows of Coastal Andhra Pradesh. Indian J. Agric. Sci., 83, 359-361 (2013).

Mishra, J.S., N.S. Thakur, P. Singh, V.S. Kubsad, R. Kalpana, U.N. Alse and S.M. Nemade: Tillage and integrated nutrient management in rainy- season grain sorghum (Sorghum bicolor). Indian J. Agron., 59, 619-623 (2014)

Mishra, J.S., N.S. Thakur, P. Singh, V.S. Kubsad, R. Kalpana, U.N. Alse, and P. Sujathamma: Productivity, nutrient-use efficiency and economics of rainy- season grain sorghum (Sorghum bicolor) as influenced by fertility levels and cultivars. Indian J. Agron., 60, 76 81 (2015).

Mishra, J.S., R. Kumar and B.P. Bhatt: Low-cost technologies for management of rice fallows in Eastern India. In: XXI Biennial National Symposium of Indian Society of Agronomy, MPUAT, Udaipur, Rajasthan, India. pp. 7-9 (2018).

Nagarajan, G.,T. Ramesh, P. Janaki and S. Rathika: Enhancement of fingermillet productivity through land configuration and nitrogen management under sodic soil. Madras Agric. J., 105, 257-261 (2018).

Naik, B.S.S.S., K.V.R Murthy, A.V. Ramana and P. Gurumurthy: Performance of sorghum hybrids under different nitrogen levels in rice-fallow conditions of North Coastal A.P., India. Int. J. Curr. Microbiol. App. Sci.,7, 3655-3662 (2018a).

Naik, B.S.S.S., K.V.R Murthy, A.V. Ramana and P. Gurumurthy: Sorghum hybrids performance on the growth, yield and chemical analysis parameters under graded levels of nitrogen in zero tillage conditions. Int. J. Chem. Stud., 6, 2400-2402 (2018b).

Nigade, R.D. and S.M. More: Performance of finger millet varieties to different levels of fertilizer on yield and soil properties in SubMontane Zone of Maharashtra. Int. J. Agric. Sci., 9, 256-259 (2013).

Olsen, S.R., C.V. Cole, F.S. Watanabe and L.A. Dean: Estimation available phosphorus in soil by extraction with sodium bicarbonate. United States Department of Agriculture. Circular number: 939 (1954).

Panse, V.G. and P.V. Sukhatme (Revised by P.V. Shukatme and V.N. Ambe): Statistical Methods for Agricultural Workers. ICAR, New Delhi, pp. 100-174 (1985).

Patil, J.V., R.R. Chapke and J.S. Mishra: Sorghum cultivation in rice fallows -A profitable option. Indian Farming, 62, 24-26 (2012).

Patil, S.L.: Productivity of winter sorghum and chickpea as influenced by integrated nutrient management in deep black soils of Bellary region, India. Indian J. Soil Conser., 41, 52-63 (2013).

Prasad, P.V.V., M. George, D.B. Mengel and T.T. Tesso: Influence of nitrogen fertilizer on growth and yield of grain sorghum hybrids and inbred lines. Agronomy J.., 106, 623-1630 (2014).

Ramyasri, K., A.V. Ramana, A.U. Rao and P.G. Murthy: Nutrient uptake vis a vis grain yield of foxtail millet varieties as influenced by nitrogen levels in rice fallows. Int. J. Curr. Microbiol. App. Sci, 7 , 2626-2629 (2018).

Ramyasri, K., A.V. Ramana, A.U. Rao and P.G. Murthy: Productivity of foxtail millet (Setaria italica L.) varieties as influenced by nitrogen levels in rice fallow of north coastal A.P. Andhra Agric. J., 66, 39-43 (2019). 
Ravindranadh, G., M.S. Rekha, B. Venkateswarlu and K. Jayalalitha: Physiological performance and economics of foxtail millet [Setaria italica (L.)] varieties to different nitrogen levels. J. Pharma. Phytochem., 8, 332-335 (2019).

Reddy, K.S.: Emerging strategies for enhancing external and internal $P$ use efficiency in different crops/cropping systems. J. Res. PJTSAU., 47, 1-8 (2019).

Sanjana, G., A.V. Ramana, A.U. Rao and P.G. Murthy: Effect of graded levels of nitrogen and foliar feeding of nutrients on performance of rice fallow finger millet. Pharma Inn. J., 9, 406-411 (2020).

Shrestha, J.: P-Value, A true test of significance in agricultural research. Retrieved from https://www.linkedin.com/pulse/p-value-testsignificance-agricultural-research-jiban-shrestha/ (2019).

Singh, R., S.K. Prasad and M.K. Singh: Effect of nitrogen and zinc fertilizer on $\mathrm{Zn}$ biofortification in pearl millet (Pennisetum glaucum). Indian J. Agron., 59, 474-476 (2014).

Subbiah, B.V. and G.L Asija: A rapid procedure for determination of available nitrogen in soils. Curr. Sci., 25, 259-260 (1956).

Wani, A.G., B.N. Narkhede and D.P. Pacharne: Performance of rabi sorghum (Sorghum bicolour L.) genotypes under rainfed conditions at varying fertility levels. Indian J. Dryland Agric. Res. Dev., 19, 61-63 (2004).

West, T.O. and W.M. Post: Soil organic carbon sequestration rates by tillage and crop rotation: A global data analysis. Soil Sci. Soc. America J., 66, 1930-1946 (2002).

Yaa, M., E.M. Mosanif, M.M. Aqil and A. Kumali: Effect of nitrogen levels on yield, competitive, economic indices and efficiency of sorghum cultivars and common bean intercropping. Agric. Res. Tech., 3, 118 (2017). 